\title{
Nota introdutória. A modernidade e a pós-modernidade em foco
}

Albertino Gonçalves e Jean-Martin Rabot”

As ciências sociais, que tinham a pretensão de antecipar os acontecimentos, mostraram-se muitas vezes em atraso sobre eles. Defraudaram a sua vocação ao pensar que deviam dirigir o mundo e dar-lhe um rumo certo, um rumo que era inerente à história do Ocidente, à maneira como este sempre se concebeu, em virtude das suas raízes judaico-cristãs: o rumo da cidade celeste (Santo Agostinho), o do controlo da natureza (Descartes), o da imposição da liberdade (Rousseau), o do reino dos fins como resultado da autonomia da vontade (Kant), o da perfectibilidade do Homem (Condorcet), o do estado positivo (Comte), o da emancipação do Homem (Marx), o dos princípios de justiça (Rawls). É como se o Ocidente não pudesse conhecer outro caminho do que aquele que a razão universal traçou para ele. A raiz judaico-cristã do Ocidente alastrou-se a todos os domínios de actividade, inclusive à especulação filosófica e científica, assim como à experiência política. É como se a teologia desembocasse necessariamente numa teleologia, e que esta contaminasse, por efeito de contágio, a filosofia, a ciência e a política. Daí que Julien Freund tenha advogado uma filosofia que fosse filosófica, ou seja, que permitisse multiplicar até ao infinito as perspectivas de apreensão do ser e de atribuição de sentido ao mundo e à existência, em vez de determinar de forma unidimensional o que deve ser e advir. É assim que Michel Maffesoli defende uma sociologia que seja compreensiva em vez de explicativa, descritiva em vez de analítica, insistindo sobre a raiz comunitária e, por conseguinte, sentimental e passional do político. O presente recupera motivos do passado que são adaptados à modernidade. O tempo do filósofo-rei ou do sociólogo-rei já passou.

Talvez tenham sido os próprios desígnios e símbolos da modernidade e o seu princípio de acção, a racionalidade instrumental, enquanto motor de um progresso ilimitado que passaram de tempo, assim como as narrativas de legitimação deste progresso. A verdade é que tudo acaba por passar de tempo. Mas é preciso saber reconhecê-lo. É desacertado pensar que as sociedades modernas possam reproduzir até ao infinito o

\footnotetext{
* Centro de Estudos em Comunicação e Sociedade (CECS). Universidade do Minho.

albertino@ics.uminho.pt

jmrabot@ics.uminho.pt
} 
seu modo de ser originário, ao inscreverem-se no tempo da linearidade, no esquema do progresso contínuo. É até insensato pensar que qualquer vestígio do passado tem necessariamente que desaparecer. Para além da labilidade social, existe um fundo invariável na vida dos homens a que os sociólogos deram nomes diferentes: o motivo em Weber, o resíduo em Pareto, as formas elementares em Durkheim, as estruturas antropológicas em Gilbert Durand, etc. Se podemos ver na modernidade uma incarnação do mito prometeico, podemos ver na pós-modernidade uma reactualização do mito dionisíaco, com a parte de confusão e de fusão que comporta. À história orientada para um determinado sentido responde a visão cíclica, característica da redundância do mito.

A pós-modernidade condiz com o "apagamento do futuro", se quisermos utilizar a expressão de Jacques Ellul. Corresponde ao enfraquecimento da crença incondicional no progresso, enquanto marca singular que pontuou a história do Ocidente, em particular a partir do século XV: o Renascimento, a Reforma Protestante, a filosofia das Luzes, a Revolução Francesa, a Revolução Industrial, o progressismo marxista, a instauração de regimes totalitários e de democracias liberais e socialistas no século XX. Naturalmente, a pós-modernidade corresponde ao desmoronamento dos grandes discursos de referência que legitimavam a crença no progresso, à semelhança da "narração crística do amor mártir" (Lyotard) e do marxismo. A pós-modernidade anuncia assim o fim do prometeísmo da civilização ocidental no seu papel de arauto de uma ordem mundial que se encarrega de "garantir o crédito em geral, o crédito no sentido financeiro e o crédito conferido às linguagens", como no-lo diz Jacques Derrida. A depreciação dos paraísos celestes e terrestres abriu o caminho para a valorização do presente, a concretização do princípio de prazer na vida quotidiana. A sociologia, no entanto, nem sempre soube mostrar-se à "altura do quotidiano" (Weber).

Talvez devamos reconhecer que a noção de pós-modernidade não se enquadra matematicamente no rigor científico do conceito - rigor que, muitas vezes, torna os conceitos rígidos. Por essa razão, alguns autores tentaram esquivar-se à palavra "pós-modernidade”, em prol todavia de noções não menos equívocas. Por meio delas, umas vezes pretenderam mostrar que a pós-modernidade corresponde a uma radicalização da modernidade; outras vezes, que a pós-modernidade não pode ser pensada fora do contexto da modernidade. Noutros casos ainda, a pós-modernidade foi invocada apenas para se lhe imputar a incapacidade de salvaguardar as conquistas da modernidade. Falou-se em modernidade tardia (Giddens), em modernidade líquida (Z. Bauman), em sobremodernidade (M. Augé, G. Balandier), em hipermodernidade (Lipovetsky), em ultramodernidade (F. Lenoir). Forçoso é reconhecer que as críticas da noção de pós-modernidade se cruzam com a denegação da ideia de politeísmo. Inúmeros autores recusam por completo a ideia simmeliana, segundo a qual o fenómeno religioso se resume à "intensificação e à absolutização da relação social" (Simmel), desprezando aquilo que Aron chamou de "ordem heterogénea dos valores" e Vattimo de "mundo babélico do pluralismo".

A palavra-chave da filosofia e da sociologia racionalistas, que caracterizam a modernidade, tem sido a "unidade". Tanto uma como outra ignoram que a marca da realidade é a pluralidade. Aliás, “a dialéctica, a poesia, o erotismo, a mística e, no âmbito 
da história, a guerra e os conflitos internos" (Octavio Paz) desfizeram sempre os sonhos pacificadores daqueles que James Burnham denominou de "organizadores". Mais vale então permanecermos fiéis à tradição sociológica, aos autores que não se deixam levar pelos discursos conformistas, normalizadores e politicamente correctos, e zelar, na óptica da "teologia politeísta" preconizada por David Miller, pela produção de um pensamento que esteja em consonância com o seu tempo, que seja capaz de coadunar a reflexão plural com o pluralismo das práticas sociais e das suas mais variadas expressões na vida quotidiana. É a esse intento que respondem os textos desta revista.

Os primeiros capítulos deste número de Comunicação e Sociedade propõem-nos uma reflexão aprofundada sobre a modernidade, a pós-modernidade e o imaginário social. O segundo tópico da revista está organizado à volta da temática das novas tecnologias, média e comunicação. Seguem-se tematizações sobre a cidade, as identidades e o tribalismo. Finalmente, apresentamos questionamentos sobre o jornalismo, e são feitas leituras de obras contemporâneas. 